\title{
Corpo-bureaucratizing Community Forestry: Commercialization and the Increased Financial Transaction in Community Forestry User Groups in Nepal
}

- Dinesh Paudel*, Dil Babadur Khatri**and Govinda Paudel**

\author{
PhD student, University of Minnesota. \\ ${ }^{* *}$ ForestAction Nepal \\ Corresponding author: khatridb@gmail.com
}

\begin{abstract}
Based on the analysis of financial transactions and decision making procedures in Community Forest User Groups (CFUGs) in Nepal, this paper argues that communit forestry is adapting techno-bureaucratic and corporate culture, replacing indigenous ways of community governance and by placing market elements into existing hierarchies and power asymmetries of local communities. It also argues that the trend of commercialization in community forestry has increased not because of the rational economic decisions made not on the basis of increased demands and surplus supply but because of a combination of on the basis of increased contion of economic and non-econon as the next possible step in community-managed resources. In doing so this paper attempt to understand the dynamics, mechanisms and extent of CFU Gs financial transactions through conceptualizing links of community forestry with extra-local economic forces, and also provides alternative ways of managing community resources for increased pro-poor outcomes. This study is based on in-depth analyses of national and district databases of CFUG funds, and ethnographic studies of 8 selected CFUGs from different parts of the country.

Key words: community forestry, commercialization, income, poor, governance
\end{abstract}

\section{INTRODUCTION}

Promoting economic activities by commercializing natural resources at a local level has been the main thrust of contemporary development. This endeavor is justified not only as a possible source of capital for states, communities and entrepreneurs, but also as a way of conserving the environment, achieving social equality, individual freedom, and the overall wellbeing of society and nature (Scheer et. al. 2004). Commercialization has been carried out as development work, especially in the global South, which encompasses a range of activities including empowerment and income generation (e.g. Li 2002; Sneddon 2007). Recently, the focus of commercialization has shifted to resources such as forestlands, fisheries, and watersheds, which are owned and managed by indigenous communities.
Nepal's community forestry is one of the revealing examples of a successful program to involve communities into the scheme of community-based management and commercial utilization of forest resources. In the thirty-year journey, community forestry has been successful in forming more than 15,500 Community Forest User Groups (CFUG) and mobilizing almost eight million people (one third of the national population) as active participants (MOFSC 2008). From the beginning, community forestry has been changing its focus and objectives to be in line with the continuously shifting ideas and concepts in international development discourse. The original focus was to develop forests to supply forest products to the community members to fulfill basic needs during the 1970s and 1980s (Gilmour and Fisher 
1991). During the 1990s, the priority shifted to develop institutionally robust community groups and economically productive forests for the maximization of economic benefits (Hobbley 1996). In recent years there has been a shift towards commercialization of forest products to generate increased financial benefits. With interventions towards commercialization, some CFUGs have increased their financial transactions and size of their fund tremendously over the last ten years. Such increased financial transaction at the local level however, has not generated any substantial pro-poor outcome, and the inequality in distributing resources has been further exacerbated (Pandit et al. 2008).

This paper attempts to understand the dynamics, mechanisms and extent of CFUGs' financial transactions through conceptualizing links of community forestry with extra-local economic forces, and also provides alternative ways of managing community resources for increased pro-poor outcomes. In doing so, we have examined sources of income, distribution of expenditure, and dynamics in decisionmaking while formulating investment policies of the CFUGs. This paper argues that community forestry is adapting to technobureaucratic and corporate culture and replacing indigenous ways of community governance by placing market elements into existing hierarchies and power asymmetries of local communities - It also claims that the trend of commercialization in community forestry has increased not because of the rational economic decisions made, on the basis of increased demands and supply, but because of a combination of economic and non-economic factors that create conditions necessary for commercialization as the possible next step in community-managed resources. This study is based on analyses of national databases of CFUG funds, and ethnographic studies of eight CFUGs from eight different districts of the country.
The article is organized into six sections including this one. The second section highlights some of the major shifts in Nepal's community forestry which have encouraged commercialisation in CFUGs. The third section provides an analysis of sources of income of CFUGs at various levels. The fourth section analysis the distribution of expenditures of CFUGs' funds. The fifth section discusses the dynamics of financial transactions and the issue of equity. At the final section, we offer our conclusions.

\section{TOWARDS COMMERCILIZATION}

Community forestry in Nepal has gone through a number of shifts at conceptual, methodological, and operational levels over the last three decades. These shifts are congruent with the changes in economic, political, and environmental aspects of Nepal and with changes in global developmental paradigms. As a result, community forestry has been recognized as a major programme in endeavors of economic growth, democratic processes, and rural transformation. These transformation have moved community forestry from a local/ indigenous program to fulfilling the larger interests of market development and environmental governance, such as the payment for environmental services (Matta and Kerr 2006; Pokharel et al. 2009). Due to the enormous efforts made by local communities the condition of community forests has improved significantly, resulting in the stocking of valuable forest resources, including timber and non-timber forest products (Iversen et al 2006). This has created tremendous opportunities for commercialization. Likewise, conceptual and operational changes in community forestry have vastly transformed the community dynamics at a local level, in terms of group collectivity, decision-making, and generating financial resources and its mobilization. Specifically, the amount and sources of income have increased enormously 
(Acharya 2002), and the distribution of expenditure has diversified across various areas of investment, ranging from local development activities to national socio-political events.

Thus, community forestry has shifted its main focus from securing subsistence requirements of communities towards maximization of profits by satisfying demands of the market (Pokharel et al. 2006). In recent years, there has been a growing trend of involvement of CFUGs in commercial activities. Such a shift is gradually demanding the CFUGs to act as an entrepreneurial institution in managing community forests and implementing various development activities (Acharaya 2003; Pokharel et al. 2009). Likewise, community forestry has shifted its focus to various social and political agendas, such as good governance, poverty reduction, democratic practices, and representation; in addition to environmental protection which was the main thrust when it was first introduced. This change has affected not only on how communities operate in everyday practices, but also on their internal dynamics for the allocation of resources and setting of priorities. Traditional power structures have changed, and as a result, a new set of actors have emerged. Simultaneously, community forestry has moved away from indigenous collaborative and informal practices and are adopting formal standards, rules and regulations. This shift has introduced a new set of institutional mechanisms and bureaucratic systems to manage diverses CFUGs activities. These changes have led to systematic management of financial resources in some cases and corruption and mismanagement in others.

In addition, community forestry started on the premise of locally contained (and also isolated from the radar of the state) community practices. However, in recent year's community groups have been thriving in collaboration and partnership with external institutions such as Non Govermental Organisations (NGOs), the private sector, academics and political forces (Chapagain and Banjade 2009). This extended connectivity has increased the role and stake of outside institutions in the planning and implementation of CFUG related activities. Therefore, the community forestry is no longer a local system of forest management; rather it is an interface between local communities and external actors. Such an interface has generated various economic opportunities in a broader sense, but at the same time locally specific issues and concerns of marginalized groups have been undermined.

Finally, the meaning of forest management in community forestry has changed dramatically over the last ten years (Pokharel et al. 2007) The market is increasingly playing a bigger role in deciding which forest types are worth growing. Nevertheless, the scope of forests has gone beyond the production of consumable products because of the introduction of environmental services as commodities for the market. This has generated new possibilities and at the same time demanded stronger institutional arrangements and financial management.

The above changes had a direct influence on the financial growth, transactions and management of CFUGs. Nevertheless, community forestry has already encountered different issues, such as equity and democratic governance (Rai Paudyal 2008; Thomas 2008). Commercialization has mostly benefited local elite members, government officials and contractors (Iversen et al. 2006 Yadav et al. 2008), marginalizing the poor people. Therefore, careful assessment of CFUGs' financial situation has become one of the urgent tasks for conceptualizing an alternative approach to CFUG's financial decisions.

\section{SOURCES AND STATUS OF INCOME}

\section{IN CFUGs}

Along with the success in conservation and management of the forest, CFUGs have also 
diversified their sources of income over the last ten years mainly through commercialization. Though the main source of the CFUGs is distribution and the sale of forest products within and outside the group, they have been generating income from other internal (membership fees, fines, interest on loan etc.) and external (donation, grant, prize, visitor fee etc.) sources. The miscellaneous sources of income are vague and difficult to define, but they do make up a significant amount in some cases. This section examines sources of CFUGs' income and their distribution from national database and samples of Hill (NTFP rich) and Terai (timber rich) districts, and indepth ethnographic analysis of selected casestudies CFUGs.

CFUGs' Sources of Income at National Level (all districts)

The income of CFUGs has been found to be tremendously different in the different geographical locations (higher income in the Terai and lower in the mid-hill). A number of factors influence such income variations. These include access to infrastructure, abundance of timber and NTFPs, connection to contractors, leadership of entrepreneurs in CFUGs, increased project's and NGOs' support, and the availability of local markets. Not all CFUGs have commercialized the forest but commercial mechanisms have been introduced or adapted in distributing forest products internally in many of them. Internal biding, cash deposition before collecting forest products, price for certain quota of forest products and fines are very common income sources across the country. In this way, the major income of CFUGs that are not involved in commercial sales also comes from the royalty-based distribution of forest products among CFUG members.

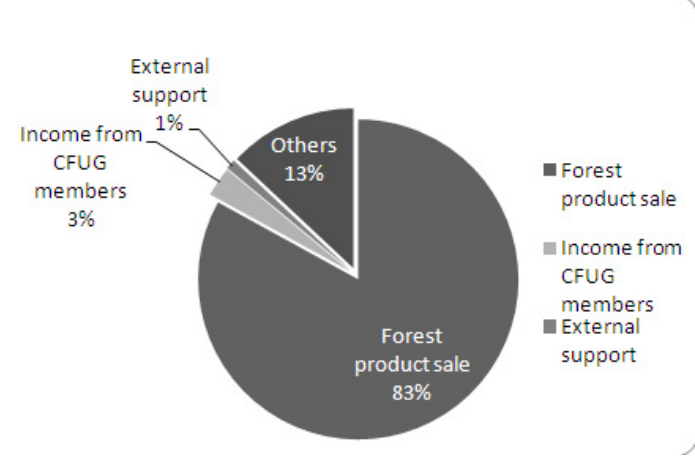

Figure 1: Annual Income ofCFUGs in FY 2008/09

The sale of forest products comprises $83 \%$ of the total income, which includes funds from internal distribution and from sale in the market. Although the income from the sale of forest products highly outweighs other sources of revenue at a national level, this is less so in the mid-hills and in CFUGs with less forest area. Similarly, the grants and direct financial support from donor organizations, NGOs and the government accounts for less than $1 \%$ of the total income. Likewise, the financial punishment to defaulters has gone up, however the power dynamics within CFUGs play a significant role in this process. Lastly, the miscellaneous sources are always hard to disintegrate into details. Most CFUGs have kept their detailed records, but the national recording system is not compatible to record CFUGs' diversified sources of income.

\section{Sources of Income in Hills and Terai}

The commercial distribution of forest products is found to be the main source of income in both Terai and the Hills. However, the ratio of income from forest products is much higher in the Terai compared to the Hills. For example, $93 \%$ of the total income of CFUGs in FY 2008/09 (Rs 76.3m) was from the sale of Sal timber to the contractors in the Udayapur district, which is one of the leading timber 
exporting districts in the Terai. The total income from the forest products comprised $85 \%$ (Rs $4.83 \mathrm{~m}$ ) in Lamjung district in the mid-hills. Dolakha district from the upper mountain region received $78 \%$ (Rs $2.9 \mathrm{~m}$ ) from the sale of forest products. CFUGs in the hills sell their forest products mainly to their members (10 to $20 \%$ of the market price) therefore the total income is less than in the Terai where the bulk of timber is sold outside CFUGs at a market price. The income from CFUG members (fines and membership fees) is the second largest source of income and comprises 2.2\% (Rs $1.9 \mathrm{~m}), 4.5 \%$ (Rs 252,784) and 17\% (Rs 641,210) in Terai (Udayapur), mid-hills (Lamjung) and high hills (Dolakha) respectively.

These figures indicate that CFUGs in the hills are less dependent on the market for their income than in the Terai, where market provides more than $90 \%$ of their total income. The saving from previous years is very high in all districts. The expenditure (investment) is very high in the Terai region whereas CFUGs in the hills have a tendency to save in the form of cash (deposited in the bank in most cases)

The number of households and the size of forests are the two main variables that determine sources and size of income in CFUGs. The total handed over forests and total number of CFUGs and households are different in different districts. The average income of $100 \mathrm{hh}$ of CFUG in Udayapur district was Rs 165,464 in FY 2008/09 (average annual income of Rs 1670 per household) whereas the average annual income of $100 \mathrm{hh}$ in Lamjung district was Rs 22,940 (around Rs 222 per household). The figure of annual income in high hills (Dolakha) was less than Rs 9,620 for every $100 \mathrm{HH}$. While considering income from the average forest area, the CFUGs in the Terai (Udayapur) have received Rs 128,760 from 100 hectares of community forests whereas it was Rs 40,700 and Rs 9,250 in the mid-hills and high hills respectively.

\section{Sources of income in case study sites}

A total of eight CFUGs were selected from eight districts to study in-depth dynamics of financial transaction. The analysis of three and five CFUGs in the Terai and the hills respectively shows that the sale of forest products has been the main source of income (see figure 2), comprising $76 \%$ of the total income. This is $5 \%$ less than the national average $(80 \%)$. The total income of three CFUGs from Terai in FY 2008/09 was Rs 3.2m. The income from miscellaneous sources includes paid back loans, bank interest, clearance of advances and defaults (Beruju), income from visitors and some unidentified sources. An interesting point to note here is that Gaukhureshwer CFUG of Kavre has been receiving a considerable amount of ncome from visitors (tourism). The external support to the CFUGs is very nominal.

The average income from 100 hectares of the Terai forest has been providing huge financial

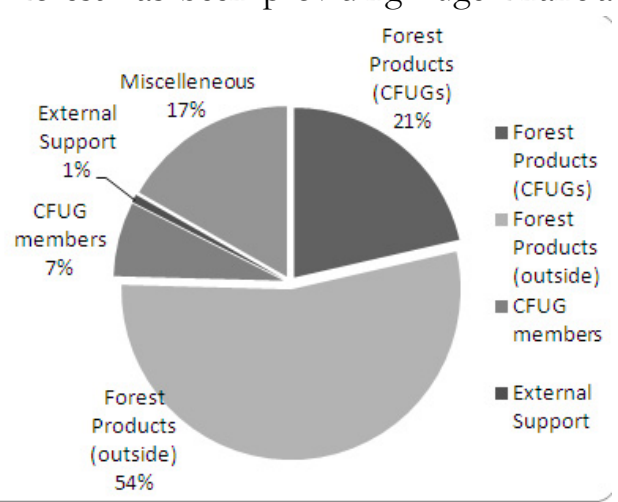

Figure 2: Income of eight sample CFUGS

benefits to CFUGs (Rs192,326 from every 100 ha), compared to Rs 59,940 in the hills. This shows that the productivity and condition of the forest determine the sources and size of income. Similarly, the level of income based on number of households in CFUG resembles the findings of national level data analysis. The average income of CFUG in Terai with 100 households was Rs 112,480 in FY 2008/09 whereas this figure was only Rs 54,168 in the Hills. 
Most CFUGs have been collecting 'royalties' (an amount equivalent to government tax) rather than the actual market price of forest products. For example, one cubic feet of $\mathrm{Sal}$ timber costs Rs 2500 in Kathmandu and at least Rs 1200 in local markets. But the average timber price at CFUG paid by the contractors is Rs 300 per cubic feet. This indicates that the full potential of benefits is not harnessed at CFUG level.

PATTERNS OF EXPENDITURE IN CFUGs

The involvement of CFUGs in community development activities has increased substantially over the last ten years. This has demanded a huge CFUGs' expenditure. CFUGs have invested their funds in six major areas - propoor activities, community development, forest development, enterprise development, institutional development, and democratic development. The items of expenditure are recorded differently in different districts and such diversified recording systems have complicated the categorization and interpretation of expenditures in a coherent way at a national level. This section explores the major patterns of expenditure at national, district and CFUG levels by analyzing databases and ethnographic information.

CFUGs' Expenditures at National Level (all districts)

The national data-base shows that CFUGs have spent only $50 \%$ of the total annual income $(\$ 5.71 \mathrm{~m}$ out of $\$ 11.43 \mathrm{~m})$ in developmental, institutional and administrative activities in FY 2008/09 (see figure 3). CFUGs have spent the highest amount - 36\% (Rs $148 \mathrm{~m}$ ) of their total expenditures - on the development of rural infrastructure (roads, schools, irrigation channels, drinking water, etc.), while the propoor programs (scholarship, grants, income generating activities, soft loans, seed money, share in enterprises) received least priority, spending only $3 \%$ (Rs $12.5 \mathrm{~m}$ ) of the total. The average expenditure per CFUG on pro-poor activities was Rs 817 compared to Rs 9,546 in infrastructure development, Rs 8,140 in forest development, and Rs 3,848 in institutional development per CFUG in FY 2008/09.

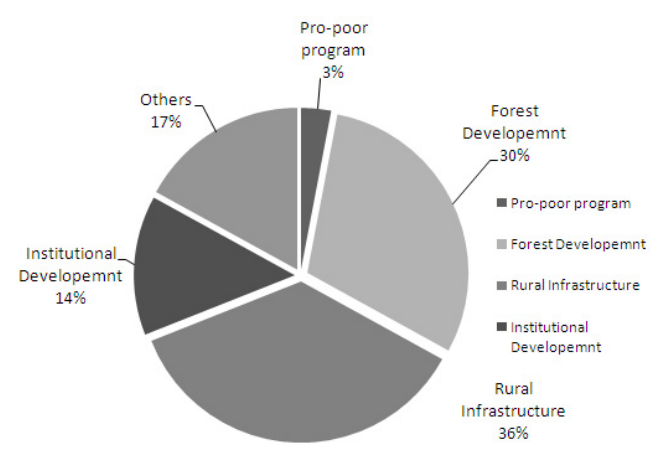

Figure 3: Annual Expenditure CFUGs 2008/09 (US $\$ 5.71$

A huge amount of money was spent as miscellaneous expenses comprising 17\% (Rs 4,662 per CFUG, six times higher than the expenditure on pro-poor activities) of the total. Expenses on various decision-making practices, donations to political parties, and corruption and bribery (if these expenses were recorded at all) fall under the miscellaneous heading (named as 'others'). The details of miscellaneous expenses are not recorded in the national database system. The reason behind this is that the national data-base is developed based on CFUGs' financial auditing reports, which do not provide details and explanations on expenses. CFUGs have adapted the government's financial auditing system, which is less detailed and manipulative.

\section{CFUGs' Expenditure in the Hills and} Terai

The items of expenditure are diverse and the amount of investment in each heading of expenditure is higher in the Terai region. For example, CFUGs in the Terai (Udayapur) spend $65 \%$ of the total income (Rs $52.5 \mathrm{~m}$ out of Rs 
$82.14 \mathrm{~m}$ ) in FY 2008/09, whereas in the mid- under the name of 'technical assistance' without hills (Lamjung), the figure was 45\% (Rs 5.44 receipt in order to receive permission to extract million out of Rs 12.31 million incomes). The forest products easily (see Box 1). The Box 2 pro-poor investment was $10 \%$ of the total gives an overview of how corruption is investment in the Terai, whereas it was $6 \%$ in institutionalized in the commercialization the Hills.

Box 1: Interference of DFO's in forest product extraction.

A chairperson of a CFUG in Nawalparasi says "in reality, community forests are still under the control of DFO. Although the CFUG is officially allowed to sell timber independently, in practice, DFO puts stamp on each piece of timber. We are not allowed to extract sand and gravel from the forest, but we are forced to pay $5 \%$ of our annual income to District Forest Development Fund. We do that because we have to please forest officials to avoid burdles for extraction and sale of timber".

The average expenditure per household was Rs 1060 in the Terai (Udayapur district) compared to Rs 165 in the high-hills (Dolakha) and Rs 380 in the mid-hills (Lamjung). The institutional development expenditure was less than $15 \%$ in the hills whereas it was $23 \%$ in the case of Terai. Similarly, the miscellaneous expenses were remarkably high in both cases, which were not well explained in the financial documents, leaving room for maneuver. The investment on forest management per hectare was found to be very high in the hills compared to the Terai.

The expenditures on enterprise development fall under the heading of forest management for many CFUGs. However, the corruption and maneuvering of the community fund are the main aspects of local expenditure in CFUGs. Corruption happens in two ways at local level: firstly, contractors provide money to officials, committee members and often FECOFUN leaders which are not included in the account of CFUG income. Secondly, CFUG leadership also provides money to government officials
Community forestry program in some districts is still supported by bi-lateral donor agencies, but the patterns of expenditure in both supported and not-supported districts were very similar. Despite a higher level of investment in institutional development and governance in supported districts, the miscellaneous expenses were also remarkably high. Development projects have provided financial supports to community forestry activities without properly recording such investment as CFUG's income and expenditure through their accounting system. This tendency has not only misled the financial status of forest user groups, but also weakened the control and legitimacy of the
Box 2: Economy of Sal timber (Rs/cft)
1. Royalty to CFUG 375
2. VAT
3. Forest Development Fund - 5
4. Harvesting/gathering - 73
5. DFO -25
6. Ilaka Office -25
7. Range Post - 25
8. CFUG leaders -30
9. Local movements $\quad-20$
10. Police (way to Ktm) - 4
11. Per Truck to Ktm $\quad-45000$
12. Load/Unload (per/truck) - 6000
13. DDC tax
$300 /$ truck
/district
14. Sawing cost 30
15. Market price at Ktm: $2200-2900$ 
investment itself. Financial records of the total investment made by development projects are held separately and are not reflected in income and expenditure of communities. As a result, development projects are not accountable to CFUG on one hand, and CFUGs are not claiming ownership or responsibility of such financial investments on the other.

\section{Distribution of Expenditures in Case}

\section{Study CFUGs}

Forest management, community infrastructural development and institutional expenses were the major headings of expenditure in case-study CFUGs. In most of the cases, expenses on timber harvesting, transportation and contracting were recorded under the heading of forest management. The average investment on pro-poor activities was $6 \%$ (see figure 4) which is higher than the national average. CFUGs which have been involved in forest product trade have relatively bigger amount of miscellaneous expenditure. This is because of various unseen expenditures, for example, expenses made by committee members and government officials. Interestingly, CFUGs have spent an increasing amount of their fund for the promotion of local grass-root democracy, for example, organization of special meetings and assemblies, networking with various community based organizations, taking part in

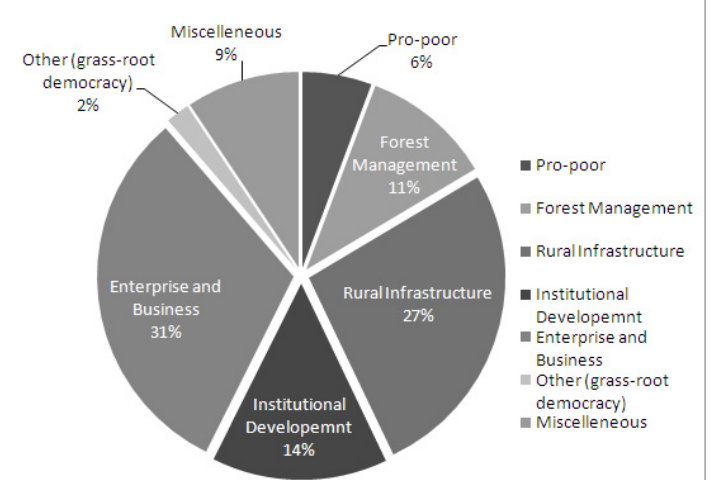

Figure 4: Expenditure of eight sample CFUGs movements and organizing public protests and rallies, which are not recorded properly.

CFUGs with the average size of 100 hectares of forests in Terai invested Rs 313,602 in various activities during FY 2008/09, whereas in the hills this figure was Rs 109,370. Miscellaneous and commercialization related expenses were very high in the Terai, but forest management and infrastructure development programs received highest priority in the hills. Similarly, the average of 100 households of CFUGs in the Terai region spent Rs 118,499, whereas in the hills the average expenditure in every 100 households was Rs 98,732 in FY 2008/09. Rs 44,576 in the Terai and Rs 66,565 in the hills were spent in every 100 households for infrastructural and institutional development programs. This indicates that CFUGs have been spending an average of Rs 445 and Rs 665 every year in the Terai and hills respectively for every household for community infrastructure and local governance. The case study shows that the investment for pro-poor programs was $6 \%$ of the total expenditure in Terai region (Rs 75 per household), whereas it was less than $1 \%$ in the hills (Rs 3.5 per household) in FY 2008/09.

\section{SHIFTING LANDSCAPE OF CFUGs}

The shifts in community forestry has not only expanded the financial transaction of CFUGs, but also created different dynamics in the functioning of local communities. The rising financial activities taking place in CFUGs are the main drivers of such transformation. But the increment in annual income and expenditure of CFUGs is not due to the development of alternative production methods; rather it is a result of collecting royalties from contractors by allowing them to collect forest products. But the consequence is that the CFUGs' institutional, personnel, and administrative costs have gone up tremendously. This change has diverted CFUGs' priorities of investment and allowed educated and elite members of the community 
control over financial disbursement and institutional development training and decision-making processes. Once the educated and 'bureaucratically' trained elite members governance related programs that focus on formal accounting systems of government and non-governmental organizations.

Box 3: Technocratic and donors decision in CFUG

The shifting focus on commercialization of CFUGs has led to extra competition among community members to get the leadership position, sometimes undemocratically, and the qualification of the treasurer is shifted from someone who is good in saving CFUG funds to educated person who can handle accounts in an 'official' way. The increased financial mismanagement and possibility of earning extra income have thus become the lucrative incentives for educated elite members to get leadership positions in CFUGs.

Similarly, the extensive partnership developed by CFUGs with multiple institutions and individuals including donor agencies, NGOs and local government, has created conditions by which voices and interests of the outsiders are stronger in community affairs (see Box 3). As a consequence, visible and invisible alliances have started to emerge, especially between community leaders, contractors and government officials in manipulating and disbursing FUG funds (see Box 4). Finally, the increased financial activities have allowed

started to take over financial management, the fund disbursement and record keeping became formalized, and the written record keeping systems in Nepali (and also in English in some cases) are institutionalized. This process is further reinforced and facilitated by the 'formal'

CFUGs to mobilize their funds for those works which would otherwise be funded by government (e.g. school, road, etc). They are also investing their fund in purchasing services from NGOs, private sectors, and government officials.

Box 4: Decision making in Timber commercialization in Udayapur Distric

Udayapur is one of the major districts to supply timber in kathmandu. Conventionally, it was the District Forest Office (DFO) who used to administer the timber extraction and marketing. These days, there are more than 273 CFUGs most of which are commercializing timber. However, the decision making for commercial sale in Terai is not straightforward. There is a complex process, which involves interplay among the powerful actors, most importantly DFO, contractors, elite committee members and FECOFUN. Such alliance has often undermined the ability and rights of local communities (CFUGs) to take necessary decisions on timber commercialization. 
First, though, the Forest Act 1993 and the Forest Regulations 1995 have provided rights to CFUGs to independently fix the price of forest products, the CFUGs in Udayapur are denied such rights. Regardless of the market price of timber, the CFUGs are forced to sell timber at the rate of government royalty in most of the cases. For example, government rovalty of raw Sal log is NRs 250 per cft; and CFUGs' average price for Sal timber is Rs 260 in Udayapur. During interaction with the vice-chairperson of Udayapur FECOFUN reported:

"Contractors establish informal relations with the committee members and government officials to get harvesting permission without competitive tender bidding. In most cases, the contractors proactively offer financial support for preparing or revising the operational plan of the CFUGs and also contribute to the budget for community development. In return, the contractors get access to extract and sell timber from the CFUGs. Similarly, government officials play an important role in this process, favouring the contractors who provide good financial benefits to them. The nature of favor ranges from easing the administrative process to be followed in the DFO to manipulating in the measurement of the timber quantity. We have been lobbing to increase the price of timber for long time. Last year, we organized discussion among CFUGs and decided to fix minimum price of timber for CFUGs, for instance, NRs 325 per cft for Sal log. However, such decisions have not been complied by most of the CFUGs. Since they have been receiving money for CFUGs activities they the bargaining capacity."

Second, the decision making process associated with timber sale and use of CFUG fund are under direct control of government offices. In the first place, there is still provision of double stamp (Tancha). It is mandatory for involving the government staffs during timber extraction. For this, CFUGs have to pay the cost of their time, but in an informal way (receipts are provided). Similarly, CFUGs are not allowed to make decisions to use the fund on their own. They need to prepare an annual plan and get approval from the DFO. In practice, committee members sit with DFO staff to prepare such plans. The plans need to reflect the interest of government officials, for example, budgetary provision for technical assistance, forest management and other technical trainings with facilitation from them and so on, to get approval from the DFO. In this process, CFUG members are forced to approve already decided plans from their leaders in CFUG assembly.

Overall, such alliance among the powerful actors driven by personal benefits has constrained the CFUGs decision making rights and ability. Though the timber commercialization in many districts in Terai has generated significant amount of FUGs fund, it had not supported the process of strengthening grass-root democracy. The local communities are not able to exercise their rights about use and sale of the very forest resources they have been managing over the years as well as the use of the CFUG forest fund.

\section{Commercial Alliances and CFUG Funds}

Commercialization in community forestry has been a 'joint' venture of multiple agencies and interests as a result of a number of institutional, economic and ecological changes that have taken place in CFUGs during the last ten years. As said earlier, the total stock of forest products has increased substantially in community forests producing a higher amount of annual

harvestable quantity than the actual demands for fulfilling subsistence requirements locally, leading to conceptualize commercialization as a 'natural' next step. Most importantly, the emergence of new form of alliances at local level especially among government officials, contractors, and the CFUG leadership has provided favorable condition for appropriating such surplus forest products in a commercial 
way (see Box 4). The attitude of government officials and external support organizations has created possibilities of such alliances at the local level. The overall attitude of government institutions and officials towards commercialization has changed positively since the introduction of various guidelines and policy documents defining concrete roles and responsibilities of involved actors. Ironically this process has satisfied both: 1) communities' expectations of earning increased financial benefits from commercialization, and 2) government officials' interests of maintaining control over commercial distribution and also gaining personal financial benefits with less legal and social risks at individual level. Similarly, the focus of community forestry development projects, NGOs, and service providing institutions has changed from institutional development to income generation and entrepreneurship at local level. This has strengthened local capacity in running commercial businesses and also generated possibilities for networking with private sector investors.

However at the local level, as soon as community forests started selling forest products extensively, a new generation of leadership started to emerge. Such leadership increasingly came from those who were active in trading forest products in the past. The new leadership has maintained direct and indirect alliances with contractors who supply forest products in the market. This shift in leadership has increased the rate of commercialization, especially in the Terai region where group size is relatively bigger. The traditional leadership, who focused on protection rather than harvesting, has been replaced by second generation leaders. The protection oriented leadership has been criticized as conservative, backward, feudal, and unproductive. This transformation has been connected with national political events and also with the increased demands for income and employment as main justifications at local level. The actual repercussion of such move is not known, but it has triggered higher (sometimes over) level of commercialization.

The burden of development has transferred to local level under the contemporary developmental paradigm. Schools, health posts, road, irrigations, and community infrastructure have been designated as local responsibility, needing more financial resources (Pokharel et al, 2006; Springate-Baginski and Blaikie 2003). The field study shows that such shifts in developmental policies have pushed communities to generate an increased amoun of financial resources by commercializing forest resources. The increased rate of commercialization and commercialization as the main income source of CFUGs has allowed market mechanisms to emerge as a primary actor in the community forestry processes in Nepal. Thus, to generate more cash, CFUGs members are expected to pay more cash to use forest products (mostly in a competitive basis if the given quota is exceeded) creating further financial burden to the poor households, who might not be able to pay the higher costs and often lost the competitive bidding. Such situations have undermined local/indigenous communal reciprocity and have rather demanded increased financial investment by each household to be able to retain membership to the forest user groups. Subsistence economy, which has strengthened the collective potentiality of CFUGs, has been undermined. Similarly, the rate of fines and punishments to CFUGs members has increased since the introduction of commercialization. This has created further restriction or surveillance at local level, in which poor and marginalized households are more vulnerable. As a result, financial records are available in a very formal format which means less educated people have lost their control over financial transaction. The increased income and 
expenditure of CFUGs is justified as a reason for adopting formal financial practices in the cost of marginalizing less educated people from the CFUGs financial activities.

\section{Towards Entrepreneurship - Changing} CFUGs' Internal Dynamics

Commercialization and the diversification of the sources of income have created different internal dynamics within the CFUGs developing themselves as commercial entities. The rate of commercial involvement and diversification of CFUG funds are related to and controlled by a number of factors that are prominent within and outside CFUGs: leadership dynamics, amount of available fund, degree of influence and control by officials and elite members, power dynamics in decision-making, facilitation of development projects, and inbuilt alliances between contractors and local leadership. These elements are directly responsible to determine which heading of investment gets priority and what size of fund is allocated to different headings of expenditure. Along with the increased involvement of external actors in determining level of CFUGs' income, the heading for investment is also diversified to satisfy various interests that have emerged from within and outside CFUG . Development of rural infrastructure has gained highest priority and the rate of investment is higher in the Terai region. Financial reinvestment through community-based entrepreneurship is lacking in most cases and the circulation of financial capital is limited by investing in infrastructure especially in roads, schools, etc.

The introduction of commercialization has demanded that the CFUGs should develop themselves as entrepreneurial institutions (based on economic rationality), but the trend of expenditure shows that CFUGs' investments are focused towards fulfilling various developmental aspirations at community level (which are otherwise the responsibility of the state) rather than reinvesting their funds in generating higher financial profits (unlike corporate institutions). CFUGs act as local community development organizations and therefore, the concept of economic rationality in allocating financial as well as other resources is not compatible with the mechanism and aspiration of community groups.

CFUGs' amounts and headings of expenditure are recorded differently at national, district and local level. This has created confusion and inconsistency in data presentation and analysis. Again, this is due to the adaption of government's accounting system by CFUGs which is less detailed, allowing room for manipulation. Similarly, there is no clear trend or consistency among CFUGs in terms of their expenditure. This is precisely because of the local situation, leadership dynamics, external influence and the differences in governance. However, CFUGs are heading towards gaining homogeneity in generating and distributing incomes due to the introduction of simila guidelines, system of commercialization, increased control/influence by government officials; similar support systems adapted by projects and NGOs, and interconnected alliances among different actors at various levels across the country.

The pro-poor expenditure in CFUGs is very low by giving highest priority in infrastructura development, institutional expenses (which go directly to the committee) and expenses related to commercialization. Innovations in spending and managing financial resources are discouraged at local level by introducing and enforcing formal regulatory practices, which has systematically marginalized illiterate people from knowing how CFUGs' funds are generated and utilized. The introduction and enforcement of such practices are in line with the interests of government officials, CFUG leaders in most cases, development organization (interventions for the improvement of governance have 
introduced bureaucratic procedures in CFUGs' structure and governance), and business sectors. This process has undermined the voices and decision making role of less powerful members, which can be seen in one of the Terai CFUG (see Box 5).

Box 5: A bureaucratic procedure in decision making in a CFUG

A CFUG committee member in Terai noticed that most of her CFUG's decisions related to commercial sale of timber are taken by an alliance of committee chairperson, forest ranger and contractors. She said "we as committee members are never asked to decide how much quantity of timber to be extracted and whom to grant the contract. Instead, it is decided jointly by chairperson, government official and contractor, and we get such information later. Most of the committee members often do not know the details".

CFUGs have directly copied the bureaucratic structure of government system, and this trend has undermined the indigenous practices of collective decision-making and informal way of verification at local level. The intervention for the enhancement of governance at local level (especially through the community forestry support projects) has reintroduced formal bureaucratic governance system rather than making CFUGs' structure as informal collective of individuals. The trends and status of CFUGs' income and expenditure are directly connected to such broader transformations that are happening in community forestry in Nepal.

CFUGs have also provided an active leadership in implementing various community development activities in collaboration with other development institutions. This involvement has increased their access to various developmental budgets allocated by local governments, non-governmental organizations (NGOs) and other community-development programs. The increased financial income has led the CFUGs to invest in diversified community development activities, but this transformation has also introduced a number of formal institutional arrangements. These increased financial transactions have made record keeping systems inconsistent, especially in the district and national level data-bases. To fit with the national data management system, CFUGs have adapted formal financial record keeping practices which provides only general information on the total amounts in fewer headings rather than detailed and segregated present ation.

\section{CONCLUSION}

Nepal's community forestry has been recognized as a revealing example of community based forest management, where local communities are acting collectively not only for managing the forests for subsistence uses but also for generating money from commercialization of the forest products and contributing on rural development. Going beyond the local system of forest management, community forestry has been increasingly revealed as an interface between local communities and global environmental and developmental transformations. Such interface has generated various economic opportunities in a broader sense, but at the same time locally specific issues and concerns of marginalized groups have been undermined. This paper has analyzed the income and expenditure pattern of CFUGs using national, district and community level community forestry database and decision making-dynamics of CFUGs related to financial transactions using ethnographic study of 8 selected CFUGs from different parts of the country.

Analysis in this paper has revealed that the economic activities or commercialization in $\mathrm{CF}$ are found to be not pro-poor and the CFUG 
funds are distributed unequally. A number of CFUGs have initiated pro-poor activities (although on a small scale) which allows the space to learn different aspects of community governance and institutional connections that produce pro-poor outcomes. It has been found that the CFUGs that are focused on subsistence securities are found to be more robust and effective in dealing with pro-poor activities than those which focus on commercialization in an old fashion. This suggests that the market-based development approach is not successful in Nepalese CF, which has failed to achieve a propoor economic growth and challenge the existing hierarchies and domination within the communities. Findings of this study have thus challenged the conventional understanding of the market. Competition is not the fundamental elements for the growth and expansion of commercialization, rather it is the emergence of alliances among dominant interest groups which make commercialization possible and operate market mechanisms.

The case of Nepalese CF has revealed that the market cannot operate in itself just based on the demand and supply curve; rather there is alliance among community elites, forest bureaucrats and contractors. Such alliance has undermined the role of community in making decision related to commercialization of forest products and financial transaction and limited the benefit to the CFUGs from the commercialization of the forest products. In many places, there is surplus production of forest products and a huge demand for them in urban areas. The commercialization in community forestry reveals how the external market mechanisms and indigenous hierarchical systems are co-constitutive and how they thrive based on each other's existence.

This suggests that the CF management and commercialization cannot fully incorporate into the market mechanism as it always leaves possibilities for alternatives. Community forestry might provide avenues for market development and profits in a short run, but at the cost of depleting resources, increased inequality and jeopardizing communal harmony, leading to eventual social unrests. Therefore, promotion of pro-poor investment at the level of CFUGs should be one of the priorities of community forestry in Nepal. The equitable outcome of commercialization of forest products in $\mathrm{CF}$ will not be possible unless an alternative is developed. Investment on productive forest management, development of pro-poor entrepreneurship model in the forest sector and devising equitable distribution mechanisms for enhancing sustainable livelihoods of rural communities are some alternative strategies for making $\mathrm{CF}$ better.

\section{ACKNOWLEDGEMENT}

We would like to acknowledge rights and Resource Institute (RRI) and Inter-cooperation Nepal for provided financial support for this study.

\section{REFERENCES}

Acharaya, K.P. 2003. Changing the Strategy for Community Forestry in Nepal: The Case for Active Management, Journal of Forest Policy 10(1): 43-50.

Acharya, K.P. 2002. Twenty-four years of Community Forestry in Nepal, International Forestry Review 4: 149-156.

Byrne, S., Pokharel, B. \& Mahat, A. 2009. Partnership results on Community Forestry in Nepal: Improving through Forest Resources.' Freiburgstrass 130, CH 3003 Bern: SDC, Swiss Agency for Development and Cooperation, South Asia Division.

Chapagain, N. \& Banjade, M.R. 2009. Community Forestry and Local Development: Experiences from the Koshi Hills of Nepal, Journal of Forest and Livelibood 8(2): 79-92

Gilmour, D.A. \& Fisher, R.J. 1992. Villagers, Forests and Foresters: The Philosophy, Process and Practice of Community For estry in Nepal. Kathmandu: Sahayogi Press.

Hobley, M., Campbell, J.Y. \& Bhatia, A. 1996. Communit forestry in India and Nepal: learning from each other. Kathmandu: International Centre for Integrated Mountain Development. 
Iversen, V., Chhetry,B., Francis, P., Gurung, M., Kafle,, G. ,Pain, A. \& Seeley,J. , 2006. High Value Forests, Hidden Economies and Elite Capture: Evidence from Forest User Groups in Nepal's Terai, Ecological Economics 58(1): 93-107.

Li, T. M. 2002. Engaging Simplifications: Community-Based Resource Management, Market Processes and State Agendas in Upland Southeast Asia, World Development, 30 (2), 265-283

Matta, J. \& Kerr, J. 2006. 'Can Environmental Services Payments Sustain Collaborative Forest Management?' Journal of Sustainable Forestry 23(2): 63-79.

MoFSC. 2008, Asia Forestry Outlook Study 2020: Country Report Nepal, Kathmandu: Ministry of Forests and Soil Conservation (MOFSC)

Pandit, B. H., Albano, A. \& Kumar, C. 2008. Improving Forest Benefits for the Poor: Learning from Community-Based Forest Enterprises in Nepal, CIFOR

Pokharel, B., Carter, J., Parajuli, R.R., Byrane, S. \& Gurung, B.D. 2009. Community forestry in Nepal as a means of Empowering People living in Poverty: An Assessment of its Social, Economic and Environmental Sustainability. Paper presented in Community Forestry International Workshop, Pokhara, Nepal.

Pokharel, B., Paudel, D., Branney, P., Khatri, D.B. \& Nurse, M. 2006. 'Reconstructing the Concept of Forest-Based Enterprise Development in Nepal: Towards a Pro-Poor Approach', Journal of Forest and Livelibood 5(1):
$53-65$

Pokharel, B.K., Branney P., Nurse, M. \& Malla Y.B. 2007. 'Community Forestry: Conserving Forests, Sustaining Livelihoods and Strengthening Democracy', Journal of Forest and Livelihood 6(2): 8-19.

Rai Paudyal, B. 2008. Agrarian Structures and Distributive Out(ames:A Shaker Publishing.

Scheer, S. J., White, A. \& Kaimowitz, D. 2004. A New Agend for Forest Conservation and Poverty Reduction, Washington D. C., Forest Trends, CIFOR and IUCN

Sneddon, C. 2007. Nature's Materiality and the Circuitous Paths of Accumulation: Dispossession of Freshwate Fisheries in Cambodia, Antipode, 39 (1), 167-193

Springate-Baginski, O. \& Blaikie P. 2003. Is Community Forestry in Contemporary Nepal Pro-Poor and Sustainable? A PolicyProcess Analysis Paper - 1, Policy Livelihood Relationship in South Asia Program

Thoms, C.A. 2008. 'Community Control of Resources and the Challenge of Improving Local Livelihoods: A Critithe Challnge of GeoFormm 39(3): 1452-1465.

Yadav, B.D., Bigsby H. \& MacDonald, I. 2008. Who ar Controlling Community Forestry User Groups in Nepal? Scrutin of Elite Theory. Paper presented at the conference New Zealand Agricultural and Resource Economics Society Conference'. 